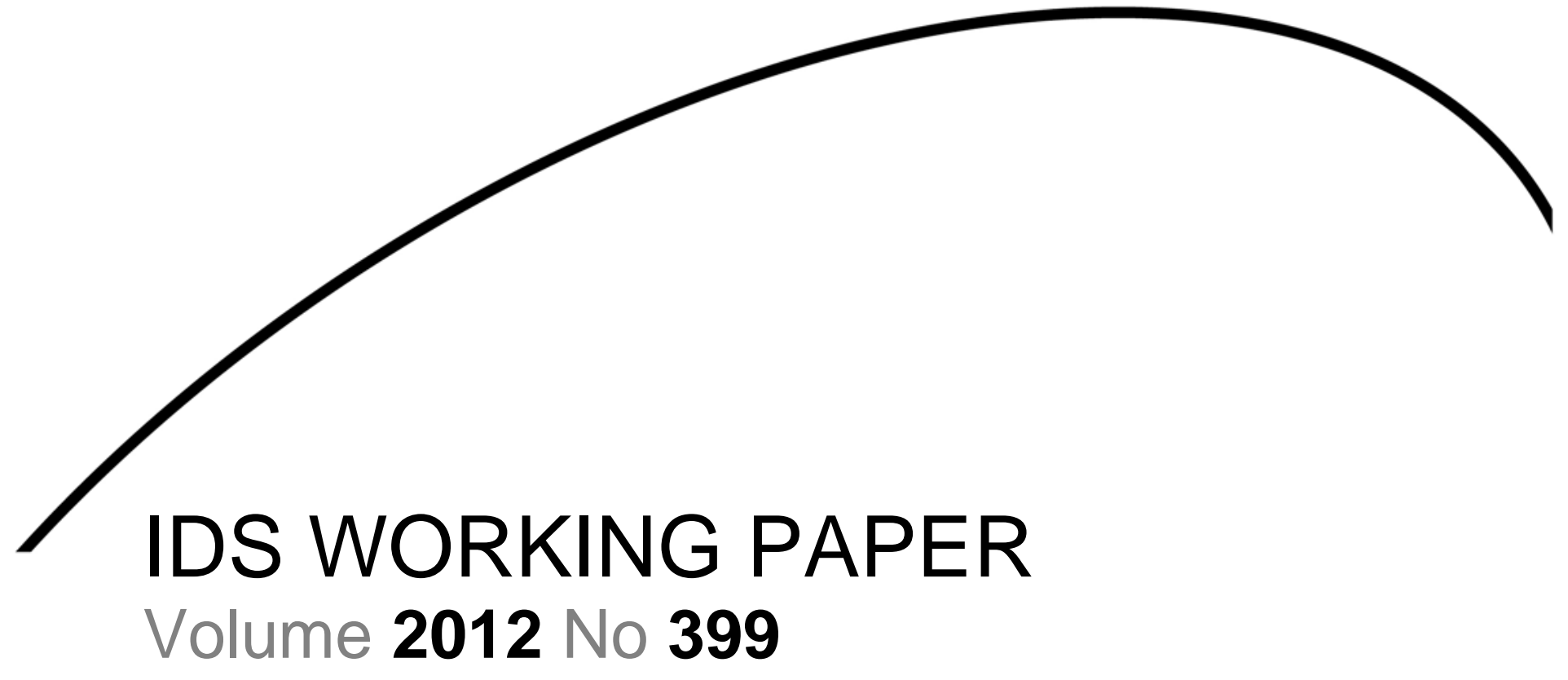

\title{
Chronic Poverty in Rural Ethiopia through the Lens of Life Histories
}

Laura Camfield and Keetie Roelen

July 2012

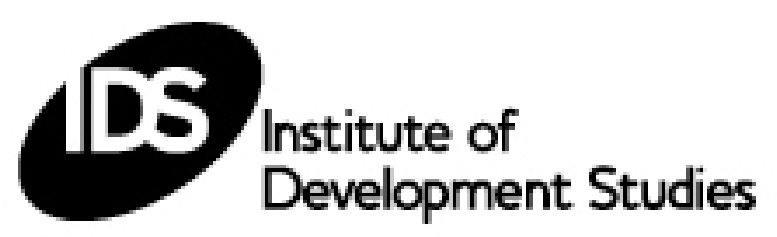




\section{(1)}

The Vulnerability and Poverty Reduction Team aims to construct dynamic and multi-dimensional perspectives on vulnerability and poverty in order to transform thinking, policy and practice

Vulnerability is a major obstacle to social and economic development. Poor people are especially vulnerable, as they have few buffers or resources to cope with hazards or shocks. They are also significantly more likely to be affected by ill-health, unemployment, trade shocks, famine or conflict. If we are to achieve sustainable poverty reduction, we must improve our understanding of vulnerability.

Email: poverty@ids.ac.uk

Web: www.ids.ac.uk/go/research-teams/vulnerability-and-poverty-reduction-team

\section{PV WP1}

A catalogue record for this publication is available from the British Library.

All rights reserved. Reproduction, copy, transmission, or translation of any part of this publication may

be made only under the following conditions:

- with the prior permission of the publisher; or

- with a licence from the Copyright Licensing Agency Ltd., 90 Tottenham Court Road, London

W1P 9HE, UK,

or from another national licensing agency; or

- under the terms set out below.

This publication is copyright, but may be reproduced by any method without fee for teaching or nonprofit purposes, but not for resale. Formal permission is required for all such uses, but normally will be granted immediately. For copying in any other circumstances, or for re-use in other publications, or for translation or adaptation, prior written permission must be obtained from the publisher and a fee may be payable.

Available from:

Central Communications, Institute of Development Studies, Brighton BN1 9RE, UK

Tel: +44 (0) 1273915637 Fax: +44 (0) 1273621202

E-mail: bookshop@ids.ac.uk

Web: www.ids.ac.uk/ids/bookshop

IDS is a charitable company limited by guarantee and registered in England (No. 877338) 


\title{
Chronic Poverty in Rural Ethiopia through the Lens of Life Histories
}

\author{
Laura Camfield and Keetie Roelen
}

\begin{abstract}
Summary
Studying chronic poverty using retrospective qualitative data (life histories) in conjunction with longitudinal panel data is now widely recognised to provide deeper and more reliable insights (Davis and Baulch, 2009). This paper uses three rounds of panel data and life histories collected by Young Lives, a longitudinal study of childhood poverty, to identify factors that contribute to households becoming or remaining poor in rural Ethiopia, with related effects on the children within those households. It combines a case-centred and a variable-centred approach (Ragin, 1987), analysing and comparing the experiences of individual households on the basis of qualitative and quantitative techniques and interrogating these findings by looking at attributes of households (variables) across a larger sample. The substantive findings on poverty 'drivers' and 'maintainers' (Baulch, 2011) support those of previous studies: rainfall, illness, debt, exclusion from the main form of social protection. But by mixing different types of data and analysis, the paper was able to show that combinations of factors rather than single events drive households into poverty, and that household characteristics can play an important factor. The primary contribution of the paper is methodological as it presents a novel method of using life histories to investigate chronic poverty in rural Ethiopia by generating or testing hypotheses/findings on poverty drivers and maintainers.
\end{abstract}

Keywords: chronic poverty; life histories; mixed-methods; Ethiopia.

Laura Camfield is a Lecturer in International Development at the University of East Anglia. Her research interests include exploring, measuring and understanding subjective well-being in developing countries; studying experiences of poverty and vulnerability using qualitative and mixed methods approaches; and children and young people. Her current focus is on enhancing the quality of cross-national methodologies used to collect data on poverty and vulnerability throughout the life course (funded by an ESRC Comparative Cross-national research grant).

Keetie Roelen is a Research Fellow at the Institute of Development Studies in the Vulnerability and Poverty Reduction team and a member of the Centre for Social Protection. Her research interests include the dynamics of (child) poverty, social protection and the linkages between child protection and social protection, and the use of mixed-method approaches to investigate them. Keetie has worked with many international organisations such as UNICEF, World Bank and UNDP, performing research and policy advice work in Southern and Eastern Africa, South East Asia and Central and Eastern Europe. 


\section{Contents}

Summary, keywords, author notes 3

Acknowledgements $\quad 5$

1 Introduction $\quad 6$

2 Literature review 1

3 Methodology 10

3.1 Content analysis 12

3.2 Qualitative Comparative Analysis (QCA) 12

3.3 Case studies 12

$\begin{array}{ll}3.4 & \text { Quantitative analysis } \\ & 12\end{array}$

4 Results 13

$\begin{array}{lll}4.1 & \text { Content analysis } & 13\end{array}$

4.2 Qualitative Comparative Analysis 14

$\begin{array}{lll}4.3 & \text { Case studies } & 14\end{array}$

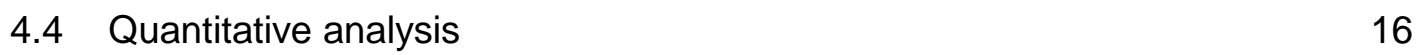

5 Discussion $\quad 19$

6 Conclusion $\quad 20$

References $\quad 22$

Tables

Table 1 Drivers and maintainers of household poverty 8

Table 2 Sample size and composition in each survey round (\%) 10

Table $3 \%$ of children having followed an upwards, downwards or stable trajectory from 2002 to 2009

Table 4 Causes of becoming or remaining poor 13

$\begin{array}{lll}\text { Table } 5 & \text { Socio-demographic characteristics } & 16\end{array}$

$\begin{array}{lll}\text { Table } 6 & \text { Life events } & 18\end{array}$ 


\section{Acknowledgements}

Thanks to Frank Ellis for his insightful review. The authors would also like to thank Yisak Tafere, Workneh Abebe, Young Lives participants and other respondents. The data used in this paper comes from Young Lives, a longterm international research project investigating the changing nature of childhood poverty (www.younglives.org.uk). Young Lives is corefunded by UK aid from the Department for International Development (DFID) for the benefit of developing countries. Sub-studies are funded by the Bernard van Leer Foundation, the Inter- American Development Bank (in Peru), the International Development Research Centre (in Ethiopia) and the Oak Foundation. The views expressed are those of the authors. They are not necessarily those of, or endorsed by, Young Lives, the University of Oxford, DFID or other funders. 


\section{Introduction}

Studying chronic poverty ${ }^{1}$ using retrospective qualitative data (life histories) in conjunction with longitudinal panel data is now widely recognised to provide deeper and more reliable insights (Davis and Baulch, 2009). The growing availability of panel data (Baulch, 2011) allows for more applications of such approaches and the extension of the evidence base around what drives and maintains individuals and households in poverty (summarised in Shepherd, 2011). This paper uses three rounds of panel data and life histories collected by Young Lives, a longitudinal study of childhood poverty, to identify factors that contribute to households becoming or remaining poor in rural Ethiopia, with related effects on the children within those households. Its primary contribution is methodological as it presents a novel method of using life histories to investigate chronic poverty in rural Ethiopia by generating or testing hypotheses/findings on poverty drivers and maintainers.

Previous research on poverty in rural Ethiopia suggests that climatic as well as idiosyncratic factors such as household illness play an important role in downward movements, particularly when these are experienced simultaneously or sequentially. Nonetheless, there is considerable variability across seasons and between regions, communities and households, as illustrated by the transition matrices in Camfield and Roelen (2011). This paper adds to the evidence base as it zooms in on those factors driving and maintaining households and their children in poverty. It combines a case-centred and a variable-centred approach (Ragin, 1987), which analyses and compares the experiences of individual households using qualitative and quantitative techniques and interrogates the findings from this stage by looking at attributes of households (variables) across a larger sample.

The analysis in this paper is mixed methods and can be characterised as 'qual dominant' (Brannen, 2005) in that we begin with a content analysis of life histories to identify factors contributing to households becoming or remaining poor. We do so across the whole of the sample for which we have life history data (32 households, 56 individuals). These factors are then included in a Qualitative Comparative Analysis (QCA, Ragin, 1987), explained later in the paper, to confirm their validity and show how they combine to drive or maintain households in poverty. We use the results of the QCA to select four case studies to illustrate these processes. Finally, we return to the quantitative data set to test the QCA results in the whole of the rural sample $\left(n=570^{2}\right)$. Methodologically speaking, the combination of household survey data and life histories is a new and emerging area (see comprehensive reviews by Baulch and Scott, 2006, Ojermark, 2007, Bird, 2011) and enables us to explore both how people in rural locations become or remain poor and how they understand these processes in relation to their life history. The combined use of these qualitative and quantitative methods, and forms of mixed methods analysis such as QCA that are rarely used within development research, will allow us to verify findings from previous research and draw more robust and generalisable conclusions. In the following section we briefly review research on chronic poverty, focusing particularly on research using mixed methods and/ or in Ethiopia. We then assess the contribution of life histories to the study of chronic poverty and highlight some methodological considerations.

\footnotetext{
${ }^{1}$ Defined in Hulme et al, (2001:12) as comprising both households who have expenditure or incomes or consumption levels in each period below a poverty line and households whose mean expenditures over all periods are less than the poverty line, but who are not poor in every period.

${ }^{2}$ This refers to individuals.
} 


\section{Literature review}

The empirical findings from quantitative and qualitative studies of why households become or remain in poverty have been summarised in various texts including Narayan (2003) and Dercon and Shapiro (2007). However, the evidence is largely correlational and the strength of the conclusions drawn is weakened by heavy attrition (Dercon and Shapiro, 2007). Also, it has to be noted that factors influencing households' movements in and out of poverty are highly variable across time and place, making it difficult to draw general conclusions. For example, Narayan et al (2009) highlight area-specific effects such as access to markets or roads, and argue that $25 \%$ of variation in social mobility across communities can be explained by country or region, while $75 \%$ of variation depends on the specific community.

Area-specific effects can be seen clearly in Ethiopia, which has a reputation as one of the poorest and most donor-dependent countries in Africa with a history of centralised and authoritarian rule dating back to imperial times. This reputation can obscure the high level of differentiation between regions, communities and households, and the speed of social change in some locations (Bevan and Pankhurst, 2007). Dercon and Krishnan (2000), for example, found that while cross-sectional studies create an impression of enduring poverty in rural Ethiopia, panel data with frequent resurveys show high variability in consumption and poverty across the seasons. Dercon (2006) reviews the progress of a panel of households during economic reform from 1989-95, including Structural Adjustment from 1992 onwards. While overall poverty fell, different villages and households had very different experiences (for example, in two of the six villages poverty increased), depending, for example, on whether they had access to a road. Bigsten et al's (2003) analysis of panel data covering 1994-97 found that the main factor supporting movement out of poverty in rural areas was the cultivation of a new cash-crop, chat, a mild narcotic that is exported to stable markets in the middle-east, although the benefits from this were distributed unequally. Devereux and Sharp (2006) find similar inequalities at the regional level in a comparative analysis of national data sets and their own data from Wollo, which show an increase in destitution and vulnerability, despite reported improvements nationally (World Bank, 1999). Finally, Woldehanna et al's (2008) analysis of survey data from Young Lives collected in 2006 found that the percentage of children from the younger cohort living in households in the lowest categories based on wealth and asset indices decreased significantly in all regions except Tigray. Across the same period the percentage of underweight children in the older cohort increased, supporting the findings of other studies that communities and households are experiencing differential changes in their level of poverty.

The differentiation in experiences of poverty described above make life history methods a good choice as they can identify factors that drive or maintain households or individuals in poverty. A range of studies using life histories have been undertaken in a variety of developing country contexts. In this paper we review studies of factors driving and maintaining households in poverty, but see also de Weerdt (2010) (Tanzania), Miller et al (2011) (Kenya), and Bird (2010) (Northern Uganda) for factors supporting households' moves out of poverty. The most comprehensive recent review of this field is Baulch's (2011) edited volume on the persistence of poverty in Africa and Asia. Baulch (2011) makes a clear distinction between poverty 'drivers' (events, processes or structures which trigger declines) and poverty 'maintainers' (institutions and processes which keep people poor), although this distinction is often hard to maintain in data analysis since respondents rarely have this degree of perspective on their own lives. Unsurprisingly, absence of household and community endowments such as assets and infrastructure and individual characteristics such as position within the household or life-stage tend to maintain people in poverty, while shocks, particularly relating to illness, drive them further into poverty (Narayan, 2003, Baulch, 2011). 
Bird and Shinekwa (2003) focus on causes of downward mobility in rural Uganda, based on 36 life history interviews. The authors show how declining trajectories are rarely the result of single events and highlight the long-term impact of family fragmentation following death or marital breakdown, often associated with alcohol consumption and domestic violence. Lawson's (2006:4-5) subsequent work in Uganda uses Bird and Shinekawa's methodology to identity 'propagators' (drivers), 'maintainers' and 'interrupters' of poverty, focusing on illhealth, assets and gender. The qualitative analysis on the basis of 43 life histories shows direct causality between sickness and movements into poverty. Davis (2011) worked with a far larger number of life histories $(n=293)$ in his study of vulnerability in rural Bangladesh. He attributes decline to a combination of lack of opportunity, acute shocks and chronic downward pressures such as ill health, and diminution of coping resources over the long term. Davis (2011) also identifies destructive coping strategies such as sale or mortgaging of land which diminish people's ability to move out of poverty in the future (see also Bird and Prowse, 2009 who address impoverishment and adverse coping using five life histories from three locations in Zimbabwe).

Kothari and Hulme's (2004) smaller-scale study in rural Bangladesh ( $\mathrm{n}=42$ households) focused on poverty maintainers, identifying gaps in state, market, civil society, and family support that locked households into poverty by preventing asset accumulation. Their paper illustrates these themes through a single story - that of Mofiz and Maymana - as well as addressing wider concerns relating to gender equality, etc. Du Toit and Neves (2007) explore context-specific sources of vulnerability such as de-agrarianisation and deepening rural inequality using life histories with key household members from 10 case study households in urban Khayelitsha (Cape Town) and rural Mount Frere (Eastern Cape), supplemented by 48 in-depth interviews with members of their social networks. Finally, Lloyd-Sherlock and Locke (2008) used 22 life histories with older respondents in Buenos Aires to demonstrate the double-edged nature of relationships with children and grandchildren in relation to the respondents' material wellbeing (for example, requests for money or childcare). These requests were so frequent as to represent an intergenerational transfer of poverty from children to parents, a theme addressed by Seeley (2008) in rural Uganda in relation to HIVIAIDS.

In Table 1 we list the 'poverty drivers' (i.e. factors causing, or associated with downwards trajectories) and 'poverty maintainers' (i.e. factors locking households into poverty) identified in Baulch's (2011) edited volume and the literature reviewed in the earlier part of this paper. We also look at the extent to which these are present in Ethiopia. In the remainder of this paper, we use our qualitative and quantitative analyses to test the continued salience of the drivers and maintainers identified here in a rural Ethiopian sample.

Table 1. Drivers and maintainers of household poverty

\begin{tabular}{|c|c|c|c|c|}
\hline & Maintainers & Source & Drivers & Source \\
\hline \multirow[t]{8}{*}{ General } & $\begin{array}{l}\text { Lack of endowments/ } \\
\text { assets }\end{array}$ & Carter and Barrett (2006) & $\begin{array}{l}\text { Combination of } \\
\text { shocks and lack of } \\
\text { resilience }\end{array}$ & $\begin{array}{l}\text { Davis (2011), } \\
\text { Shepherd (2011) }\end{array}$ \\
\hline & Lack of education & $\begin{array}{l}\text { May et al (2011), Baulch } \\
\text { and Vu (2011), Bird et al. } \\
(2010)\end{array}$ & $\begin{array}{l}\text { Two or three shocks } \\
\text { in rapid succession }\end{array}$ & $\begin{array}{l}\text { Davis (2011), Bird } \\
\text { and Shinyekawa } \\
\text { (2003) }\end{array}$ \\
\hline & Adverse geography & $\begin{array}{l}\text { Carter and Barrett (2006), } \\
\text { Dercon and Porter (2011), } \\
\text { Baulch and Vu (2011), }\end{array}$ & $\begin{array}{l}\text { Death or marital } \\
\text { breakdown }\end{array}$ & $\begin{array}{l}\text { Bird and Shinyekawa } \\
\text { (2003) }\end{array}$ \\
\hline & Ethnicity & $\begin{array}{l}\text { Baulch and Vu (2011), } \\
\text { Dercon and Porter (2011) }\end{array}$ & Family relations & $\begin{array}{l}\text { Lloyd-Sherlock and } \\
\text { Locke (2007), } \\
\text { Seeley (2008) }\end{array}$ \\
\hline & $\begin{array}{l}\text { Customs/ traditional } \\
\text { practice }\end{array}$ & $\begin{array}{l}\text { Davis (2011), Kothari and } \\
\text { Hulme (2004) }\end{array}$ & III health & $\begin{array}{l}\text { Lawson (2006), } \\
\text { Davis (2011), Kothari } \\
\text { and Hulme (2004) }\end{array}$ \\
\hline & Gender & $\begin{array}{l}\text { Kothari and Hulme (2004), } \\
\text { Lawson (2006) }\end{array}$ & & \\
\hline & Family size & Lawson (2006) & & \\
\hline & $\begin{array}{l}\text { Adverse coping } \\
\text { strategies/ diminution } \\
\text { of coping resource }\end{array}$ & $\begin{array}{l}\text { Davis (2011), Bird and } \\
\text { Prowse (2009) }\end{array}$ & & \\
\hline
\end{tabular}




\begin{tabular}{|c|c|c|c|c|}
\hline & $\begin{array}{l}\text { Gaps in state, market } \\
\text { and civil society } \\
\text { provision }\end{array}$ & Kothari and Hulme (2004) & & \\
\hline & $\begin{array}{l}\text { Macro political } \\
\text { economic factors such } \\
\text { as de-agrarianisation, } \\
\text { inequality }\end{array}$ & Du Toit and Neves (2007) & & \\
\hline \multirow[t]{8}{*}{ Ethiopia } & Chronic illness & Dercon and Porter (2011) & $\begin{array}{l}\text { Illness, medical } \\
\text { expenses }\end{array}$ & $\begin{array}{l}\text { Dercon and Porter } \\
\text { (2011); Ellis and } \\
\text { Woldehanna (2005); } \\
\text { Devereux and Sharp } \\
\text { (2006); Dercon and } \\
\text { Krishnan (2000) }\end{array}$ \\
\hline & $\begin{array}{l}\text { Living in particular } \\
\text { areas (e.g. Tigray, } \\
\text { Shoa, Wollo) }\end{array}$ & $\begin{array}{l}\text { Dercon and Porter (2011), } \\
\text { Woldehanna et al (2008); } \\
\text { Devereux and Sharp } \\
\text { (2006); Bigsten et al } \\
\text { (2003); Dercon (2006) }\end{array}$ & $\begin{array}{l}\text { Sale/ loss of land, } \\
\text { livestock and other } \\
\text { assets (e.g. to buy } \\
\text { food) }\end{array}$ & $\begin{array}{l}\text { Dercon and Porter } \\
\text { (2011); Ellis and } \\
\text { Woldehanna (2005); } \\
\text { Devereux and Sharp } \\
\text { (2006); Dercon and } \\
\text { Krishnan (2000); } \\
\text { Dercon (2006) }\end{array}$ \\
\hline & Persistent crop failure & $\begin{array}{l}\text { Dercon and Porter (2011); } \\
\text { Devereux and Sharp } \\
\text { (2006); Dercon (2006) }\end{array}$ & $\begin{array}{l}\text { Timing and quantity } \\
\text { of rainfall }\end{array}$ & $\begin{array}{l}\text { Dercon and Porter } \\
\text { (2011); Devereux } \\
\text { and Sharp (2006), } \\
\text { Dercon and Krishnan } \\
\text { (2000); Dercon } \\
\text { (2006) }\end{array}$ \\
\hline & $\begin{array}{l}\text { Lack of land, livestock } \\
\text { and other assets }\end{array}$ & $\begin{array}{l}\text { Dercon and Porter (2011); } \\
\text { Devereux and Sharp } \\
\text { (2006), Bigsten et al } \\
\text { (2003); Dercon (2006) }\end{array}$ & $\begin{array}{l}\text { Increase in family } \\
\text { size }\end{array}$ & $\begin{array}{l}\text { Ellis and } \\
\text { Woldehanna (2005), } \\
\text { Bigsten et al (2003) }\end{array}$ \\
\hline & $\begin{array}{l}\text { More household } \\
\text { members who were } \\
\text { female, young or } \\
\text { elderly and/ or female } \\
\text { household head }\end{array}$ & $\begin{array}{l}\text { Dercon and Porter (2011); } \\
\text { Devereux and Sharp } \\
\text { (2006), Bigsten et al } \\
\text { (2003) }\end{array}$ & $\begin{array}{l}\text { Death or marital } \\
\text { breakdown }\end{array}$ & $\begin{array}{l}\text { Ellis and } \\
\text { Woldehanna (2005); } \\
\text { Devereux and Sharp } \\
\text { (2006); Dercon and } \\
\text { Krishnan (2000) }\end{array}$ \\
\hline & $\begin{array}{l}\text { Being an ethnic } \\
\text { minority }\end{array}$ & Dercon and Porter (2011) & Rising food prices & $\begin{array}{l}\text { Ellis and } \\
\text { Woldehanna (2005) }\end{array}$ \\
\hline & Debt & $\begin{array}{l}\text { Ellis and Woldehanna } \\
(2005)\end{array}$ & $\begin{array}{l}\text { Falling prices for } \\
\text { produce/ services }\end{array}$ & $\begin{array}{l}\text { Ellis and } \\
\text { Woldehanna (2005) }\end{array}$ \\
\hline & Lack of education & Bigsten et al (2003) & & \\
\hline
\end{tabular}

The literature review highlights the value of mixed methods analyses of chronic poverty and of life histories in particular as a means of identifying and understanding the 'drivers' and 'maintainers' of poverty in specific contexts (Baulch, 2011). It suggests a number of hypotheses for testing, for example, that the drivers of household poverty are rarely single events and the importance of illness and lack of education for being locked into poverty (Table 1).

In the remainder of this section we look at the potential of life histories as a method to explore the drivers and maintainers of poverty (Bird, 2011). The benefits of life histories include the construction of panel-type data where a panel does not exist, the enhancement of existing panel data sets by including new variables or even by extending them back into the past, and the linking of individuals or households in the panel to their family histories (Da Corta, unpublished). Locke and Lloyd-Sherlock (2011) address some of the challenges, drawing on the authors' experiences using life histories to explore people's life courses with older people in Buenos Aires and young adults in Zambia. Their experiences highlight the importance of Glenn Elder Jr.'s (1985) concept of 'linked lives' (the role of family, friends and other individuals ${ }^{3}$ ) and wider social, economic and political changes (see also Da Corta, unpublished). The three main challenges Locke and Lloyd-Sherlock identify are making sense of disparate narratives, engaging with individual subjectivities, and situating individual experiences in dynamic social, economic and political contexts. To this we could add many of the recall biases that have been identified in relation to retrospective questions in surveys ${ }^{4}$ and a tendency among some practitioners to rely wholly on actors' accounts which can neglect the changes in social relations underpinning movements into poverty. Locke and

\footnotetext{
${ }^{3}$ See also Miller's (2007) method of collecting 'family histories' to explore the intergenerational transfer of poverty.

${ }^{4}$ Biases relating to memory may be reduced by the way the data is elicited, e.g. linking questions to significant household or national events.
} 
Lloyd-Sherlock observe that life history methodologies within development studies tend to be more thematically-focused and less open-ended than in other fields as the narratives created are analysed for what they reveal about, e.g. household coping strategies, rather than as narratives in their own right (what the authors characterise as a 'life-focused' rather than a story-focused approach). Where life histories have an advantage over the linear accounts created by quantitative analysis of panel data is in showing "the timing and sequencing of individuals' life events and transitions (and of those the people they are close to), as well as how these individuals choose to make their lives, respond to events, and interpret their experiences" (p3). Nonetheless, the authors caution that in order to make these insights into poverty dynamics "palatable to policy makers and non-qualitative researchers, it is important to strike an explicit balance between entirely unstructured methods and more focussed strategies in a way that is appropriate to the aims of the research and its intended audience" (p6).

The remainder of the paper focuses on the downwards mobility, or immobility, of households in rural Ethiopia. We tackle an acknowledged weakness of some mixed methods studies in the area of analysis by moving iteratively through multiple methods of analysis. For example, the findings of the content analysis inform the selection of variables for the QCA. We use novel approaches such as QCA, which are more commonly found in political science than development studies, and test their provisional conclusions with quantitative analysis across the whole sample.

\section{Methodology}

The analysis uses Ethiopian data from Young Lives, a study of childhood poverty in four countries, to explore the factors underpinning households' declining trajectories. Three rounds of quantitative data and two rounds of qualitative data are now available for analysis, and enable researchers to follow the same two cohorts of children over a period of seven years (this paper focuses on the older cohort). The first round of quantitative data collection took place in 2002 when children in the older cohort were 7-8 years of age. The second round of quantitative data collection took place in 2006 when the children were 11-12 years old and the third in 2009 when they were 14-15 years old. The Young Lives Ethiopian sample covers 20 sites in the ethnically-based regions of Amhara, Oromia, SNNP (Southern Nations, Nationalities and Peoples) and Tigray, as well as in the capital, Addis Ababa. Together, these five regions cover different geographical characteristics, levels of development, urban/rural locations and population characteristics (Outes-Leon and Dercon, 2008). Thirteen of these sites are classified as rural and it is these that form the basis of our analysis. There were 570 children in the rural sample in Round 3 (see Table 2).

Table 2. Sample size and composition in each survey round (\%)

\begin{tabular}{|l|l|l|l|}
\hline & $\mathbf{R 1}$ & $\mathbf{R 2}$ & $\mathbf{R 3}$ \\
\hline Boys & 52.1 & 51.9 & 52.5 \\
\hline Girls & 47.9 & 48.1 & 47.5 \\
\hline & & & \\
\hline Amhara & 25.0 & 24.5 & 24.7 \\
\hline Oromia & 24.9 & 24.7 & 24.6 \\
\hline SNNP & 25.0 & 25.2 & 24.9 \\
\hline Tigray & 25.0 & 25.7 & 25.8 \\
\hline Total $(\boldsymbol{n})$ & $\mathbf{5 9 9}$ & $\mathbf{5 8 4}$ & $\mathbf{5 7 0}$ \\
\hline
\end{tabular}

Qualitative data was collected from children and adults in four of the 13 rural sites in 2009 for a sub-study on social protection, vulnerability and social mobility, which was developed and 
managed by one of the authors. In this paper we use life history data from 56 adults caregivers of the 'index child' sampled by Young Lives - in 32 households ${ }^{5}$ across four sites in Amhara, Oromia, SNNPR and Tigray regions (eight households per site). We inserted all of the households' data in the QCA - described on the following page - to explore factors driving and maintaining households in poverty. The reasons for using all the data were that there were only two households who had not experienced poverty at any point and only five that could be characterised as experiencing an upwards trajectory (i.e. both household members characterised their trajectory as rising and this was confirmed by the taxonomy described below). In three of the sites - Tach Meret ${ }^{6}$, Leki, and Zeytuni - the sample was drawn from participants in a longitudinal qualitative study (see http://www.younglives.org.uk/what-wedo/research-methods/qualitative-sub-sample-research) (Tach-Meret is in a food-insecure area in the Amhara region, Leki is near lake Ziway in the Oromia region and produces vegetables for sale, and Zeytuni is a drought-prone area in Tigray which is highly dependent on government support). In the fourth site - Buna, a coffee-growing area in SNNP - the participants were drawn from a previous study on social protection conducted in 2008 (Emrie et al, 2009. The participants were interviewed in a location of their choice by researchers of the same gender who spoke the same language and whom they had met many times before (in some cases relationships dated back to 2001-2).

Identification of households and their children as having experienced an upwards, downwards or stable ${ }^{7}$ trajectory, which was used to tabulate the findings of the content analysis and select case study households, is based on a triangulation of respondents' own assessments of their household's trajectory and a classification of households using a mixed-method taxonomy of poverty and vulnerability by Roelen and Camfield $(2012)^{8}$.This taxonomy used Krishna's (2007) 'Stages of Progress' as its underlying theoretical framework and children's and household members' perspectives on what constitutes such different stages of progress to develop criteria for being identified as ultra-poor, poor, near-poor or non-poor (Roelen and Camfield, 2012). Table 3 presents the proportions of children having followed an upwards, downwards or stable trajectory from 2002 to 2009. Estimates indicate that more than half of all children experienced an improvement in their living conditions. However, 11 percent of all children experienced deterioration and one third of all children remained in the same situation. As only 12 percent of all children were classified as non-poor in 2002, such a stable situation represents being trapped into poverty or near-poverty for the majority of children.

Table 3. \% of children having followed an upwards, downwards or stable trajectory from 2002 to 2009

\begin{tabular}{|l|l|l|l|}
\hline & Upwards & Stable & Downwards \\
\hline Boys & 56.1 & 33.2 & 10.7 \\
\hline Girls & 54.4 & 33.8 & 11.8 \\
\hline Amhara & & & \\
\hline Oromia & 54.1 & 26.7 & 19.3 \\
\hline SNNP & 64.7 & 30.1 & 5.1 \\
\hline Tigray & 55.8 & 34.8 & 9.4 \\
\hline & 46.9 & 42 & 11.2 \\
\hline Male hh head & & & \\
\hline Female hh head & 40.4 & 33.1 & 8.1 \\
\hline
\end{tabular}

Source: Camfield and Roelen, 2011

\footnotetext{
${ }^{5}$ We interviewed two household members in every household, one male and one female (typically the mother and the father of the index child), except in the case of eight female-headed households.

${ }_{7}^{6}$ All names of sites and respondents are pseudonyms.

${ }^{7}$ The category of stable includes two subcategories of 'always poor' and 'never poor' within the period of data collection (7.5 years). The focus of this paper is stable and downwards trajectories.

${ }^{8}$ The assessments of the household members were largely in accord, although there were some interesting differences between the perspectives of male and female household members. There were two female-headed households who according to the taxonomy had moved out of poverty during the three rounds of data collection, even though they still characterised themselves as poor. In one of these cases, the household head had been imprisoned and faced a large fine for failing to guard a community irrigation pump. This was a significant event that was not captured by the variables used in the taxonomy, which may account for the difference.
} 


\subsection{Content analysis}

The content of the life history transcripts was analysed using a simplified form of Ritchie and Spencer's (1994) framework analysis, which involves i) reading and re-reading transcripts, noting key ideas and recurrent themes, ii) focusing on themes that relate to becoming and remaining in poverty (which subsequently became the causal factors for entry into the QCA see below), iii) identifying and 'charting' portions of the data that correspond to a particular theme, and iv) looking at the nature/ frequency of these across the sample and within the narratives of individual respondents and their households.

\subsection{Qualitative Comparative Analysis (QCA)}

Qualitative Comparative Analysis (QCA) was developed by Ragin (1987) as a case-centred alternative to variable-based analyses such as regression. It has been used to study causal processes in labour markets in Andhra Pradesh (Olsen, 2009) as well as UK schools (Byrne, 2009). In this paper QCA is used to verify drivers and maintainers of poverty and understand both their relative prevalence and the characteristics of the households that are most likely to experience and be affected by them. QCA requires qualitative knowledge of cases and respects both their diversity and their heterogeneity in relation to their causal conditions (for example, the way different combinations of causal conditions can generate the same outcome). The fs/QCA software uses fuzzy set theory, which indicates degrees of membership of a defined category (e.g. declining into poverty), combinatorial logic and Boolean minimisation (both compare pairs of cases, the former to identify characteristics that are not necessary to produce an outcome, the latter characteristics that are not sufficient to produce an outcome). It operates by comparing cases that differ by only one variable to work out what combinations of characteristics are necessary or sufficient to produce an outcome. It then selects the smallest number of causal combinations that will cover all the positive instances of the outcome. The main output is a 'truth table' which shows different combinations of causal factors that would be sufficient for the outcome to occur. The reliability of these configurations is assessed using in-depth knowledge of the cases and by generating a consistency score, which is equivalent to a measure of statistical significance, and a score for coverage, which indicates how many cases conform to this pattern.

\subsection{Case studies}

Within international development theorising from case studies has been used to explore causes and processes of impoverishment and exclusion in Ethiopia, South Africa and Andhra Pradesh (respectively Bevan, 2009; du Toit, 2004; Olsen, 2009). We look at processes supporting households becoming and remaining poor through the histories of particular households: 'what actually happened in this specific instance as a result of context, path dependence, the actions and interactions of protagonists, and the mechanisms and processes at work and their consequences' (Bevan, 2005:11). We have used the results from the QCA to select the four case studies to show how these causal configurations unfold in different households from two different communities (Leki and Buna, both relatively wellconnected and dependent on cash crops). The two communities represent what Yin (2003) would call 'critical cases' in that because they are connected to markets and offer many economic opportunities we might expect the factors that drive or maintain households in poverty to be less common in these settings.

\subsection{Quantitative analysis}

The quantitative analysis in this paper will be descriptive in nature, exploring the extent to which findings with respect to poverty drivers and maintainers from the literature review and qualitative analysis are mirrored by survey data from the total rural sample.

The choice of factors included in the quantitative analysis of poverty maintainers and drivers for children and their households in rural Ethiopia builds on previous evidence about maintainers and drivers in general and in Ethiopia (see Table 1 in the literature review), as well as findings from the paper's qualitative analysis. Not all factors can be incorporated in the 
analysis as explanatory variables as certain issues have already been captured by the taxonomy itself. The importance of assets, for example, is reflected in the taxonomy as it was identified by respondents as an important criteria that denotes stages of progress, or classification as either ultra-poor, poor, near-poor or non-poor (the complete list of criteria for the various categories can be found in the appendix). Furthermore, we are constrained by the variables available in the data set.

\section{Results}

\subsection{Content analysis}

The main reasons for becoming or remaining poor, i.e. drivers and maintainers of poverty (Baulch, 2011) highlighted in the life histories are summarised in Table 4, which combines the reports of female and male respondents in each household (these were close in all but a few cases of conflict within the family, for example, where the wife complained of her husband's extravagance while the husband sought to downplay the extent of his drinking).

Table 4. Causes of becoming or remaining poor

\begin{tabular}{|l|l|l|l|}
\hline Factor & $\begin{array}{l}\text { Total no: of households } \\
\text { reporting factor } \mathbf{( n = 3 2 )}\end{array}$ & $\begin{array}{l}\text { No: of female headed } \\
\text { households reporting } \\
\text { factor }(\mathbf{n}=\mathbf{8})\end{array}$ & $\begin{array}{l}\text { No: of older } \\
\text { household heads } \\
\text { reporting factor } \\
\mathbf{( n = 6 )}\end{array}$ \\
\hline $\begin{array}{l}\text { Climate (e.g. drought, timing of } \\
\text { rains, storms) }\end{array}$ & 30 & 7 & 6 \\
\hline Family illness & 24 & 6 & 5 \\
\hline High food prices & 17 & 4 & 5 \\
\hline Own illness & 17 & 2 & 4 \\
\hline Death of animals & 17 & 2 & 4 \\
\hline Exclusion from PSNP & 16 & 3 & 3 \\
\hline $\begin{array}{l}\text { Disputes (e.g. neighbours, criminal } \\
\text { authorities) }\end{array}$ & 16 & 5 & 3 \\
\hline Cost of fertiliser and seeds & 15 & 1 & 5 \\
\hline Lack of labour & 13 & 6 & 3 \\
\hline Bad debt & 9 & 1 & 2 \\
\hline Low prices for produce & 7 & 1 & 0 \\
\hline
\end{tabular}

Climate is the main reason for households becoming or remaining poor across all sites. In Tach Meret (Amhara), this is followed by family illness (7), disputes (6), and the death of animals (6). Family illness is also the second most important factor in Leki (Oromia) (6), followed by the price of food (6) (plots in Leki are small and since many farmers use them for cash crops rather than subsistence the price of grain is an important consideration). In Buna (SNNPR), the second factor is the death of animals (7), followed by family illness (6), exclusion from PSNP (6) and own illness (6). In the final site, Zeytuni (Tigray), family illness (5) and exclusion from PSNP (5) was the second most important factor. Exclusion from PSNP ${ }^{9}$ was not very important in the first two sites, which may be because quotas for PSNP exclusion were more generous, or perhaps because the programmes have not been running as long in these sites, which means that households would not have reached the five year point at which they would be expected to 'graduate'.

If we focus on the characteristics of the households rather than the sites, we can see that almost all of the eight female headed households were classified as poor or ultra-poor and categorised themselves as declining into poverty or chronically poor. For the female headed households, the main reasons for decline were climate which was mentioned by almost every household (7), followed by shortage of labour (6), which typically led to the share-cropping out of land on unfavourable terms (one quarter of the produce if the harvest was successful, nothing if it was not), family illness (6), and disputes (5), often with the family of the late/

\footnotetext{
${ }^{9}$ The PSNP, which was introduced in 2005 , aims to reduce household vulnerability, improve resilience to shocks, and decrease dependence on food aid. The programme has over 8 million participants and provides food or cash for work such as digging ditches, and direct support to a smaller number of households with no adult labour.
} 
divorced husband. With the exception of climate, the reasons for decline for households with a male head aged under sixty were very different: family illness was the most important, followed by own illness and death of animals, and finally exclusion from PSNP.

There were six households where the household head was aged over 60; these all categorised themselves as declining or chronically poor and were all classified as poor or nearly poor (they also reported slightly more reasons for becoming or remaining poor than households with heads aged under 60 ). Within this group the main reasons given were climate, which was mentioned by every household (6), followed by the cost of inputs (5), the price of food (5) and family illness (5).

\subsection{Qualitative Comparative Analysis}

While the content analysis has the effect of breaking complex histories into lists of variables to be ordered by different characteristics (e.g. gender or location), the Qualitative Comparative Analysis and Case Studies preserve the complex and dynamic nature of life histories where factors driving and maintaining poverty occur successively and in complex combinations. The content analysis generated a list of eleven 'causes' (variables) for households becoming or remaining poor that applied to the majority of case study households in different combinations (see Table 1). These were entered into the QCA following the method outlined in the methodology section.

The most common combination of causes - evident in $41 \%$ of cases - were i) climate, typically lack of rainfall (Buna was also affected by hailstorms, which damaged the coffee plants), ii) family illness, iii) lack of labour and iv) high food prices. While these were the main configurations that emerged, there were many possible combinations and few households reported fewer than five or six causes of becoming or remaining poor (range 3 to 8). Four households were selected that reported declining trajectories or chronic poverty and exhibited what the QCA found to be the most common combination of causal conditions (climate, illness, lack of labour, and high food prices) to examine how these and other factors combined in the lives of individual households.

\subsection{Case studies}

The four households are drawn from two sites, the first two from Leki in Oromia, a village where many people either grow onions and tomatoes for sale or rent their land to others for that purpose and the third and fourth from Buna in SNNPR, where coffee is grown. In choosing the case studies we wanted firstly for them to represent the most common causal configuration (see above), secondly, for them to perceive their trajectory as one of stable poverty or further decline and for this to be confirmed by the taxonomy (two were ultra-poor, one was poor and one was nearly poor; none had experienced any spells out of poverty), and thirdly for them to be from sites that were broadly comparable, e.g. because they were nearrural and market-dependent.

Ato Tufa started farming in Leki as a teenager and married his first and second wife during his early twenties (he has seven children from his first wife, with whom he has an amicable relationship, and three from his second). He didn't attend school because at that time "there was no education. It was only farming". Ato Tufa is now in his seventies or eighties - he isn't sure which - and suffers from various chronic conditions and an injured leg after falling from a cart last year. Three of his children live at home; two are attending school and one dropped out of grade 6 due to financial pressures. One of his married sons is cultivating their farmland. His youngest child is 14 and attends school, works on the vegetable farms, and does all the household chores. He perceives their main problem as lack of rain - "there is no problem when there is rain" - because this means that they don't have a regular income. They have been members of PSNP for four years, although he is now unable to work due to his age. The household receives 100 ETB per month, which is the amount for two persons rather than five (this is the result of a recent reduction in the quota). The payment is enough to purchase food, but not to acquire assets or cover other expenses such as medical treatment - "we sell grains 
when we have some. What can we do? Health should be given priority. When we don't have grain, we sell cattle". They have been told they will be excluded from the PSNP in the next round. His main concern for the future is the rising cost of living - "I think day and night. I wonder what I could do to cover such and such expenses".

Ato Gemechu has lived in Leki all his life and his wife comes from the neighbouring village. They have eight children, four of whom are married (their youngest child is 10). They did not go to school - he started working aged 10 and she was running the house and looking after the children of first her aunt and then her stepmother until she married aged 13. She recalls how "living with your mother and another woman is not the same. I was raising their cattle and children". One of their sons was very sick as a child and they sold the remainder of their livestock to cover his treatment (eight cows had died that year of a mystery illness). Their youngest girl has had a swollen gland in her neck for the past three years, but the cost of most of her treatment has been covered by a foreign investor. Currently the household's problems are declining production (they cannot afford fertiliser), pests and diseases, and rising prices. They were 'graduated' from PSNP two years ago, against their wishes, and so depend on their children's labour on the vegetable farms (only one of their children is currently in school), selling goats, and borrowing from neighbours. They have irrigated land - this was the reason why they were graduated - but rent this on unfavourable terms as they do not have oxen to plough it. They also received two cows from SIDA, but these died, possibly after having the evil eye from their neighbour: Wukro Hanamariam recalls that "the man once pointed to the cow and said: "this is a special cow, what a cow!" It was not too long before she got sick". Ato Gemechu says that they experience recurrent poverty due to crop failure as "in the winter we do not face problem. But in summer we finish all our food stuffs and the family always suffer from hunger". He notes that food prices are rising and last year Teff reached 600 or 700 ETB per quintal. According to his wife he drinks heavily and has done so for 15 years; she remarked dryly that "he always has the money for that. He tills other people's lands and gets some money. [...] I don't even ask him [...] to give me the money he earns from outside".

Wukro Tagesu studied to grade 6 but left school when she married, which she now regrets. Her husband was a soldier and after his return from the war he developed diabetes. This caused his death despite large expenditures on healthcare (she sold their livestock - a cow and an ox - to cover these). She has five children - the eldest is 17 - and struggles to provide for them and send them to school at the correct age: "the major problem I face right now is that I could not fulfil my children's basic necessities like exercise books, clothes, etc. This is what worries me most". One of her children has dropped out of school due to an eye illness which she could not afford to treat. The household received support for PSNP for one year, but was then excluded. She feels that this was unfair - there are other, wealthier participants and attributes it to being a single woman without anyone to argue her case with the kebele: "There was this meeting, without my presence, for selecting people for the Safety Net program. Some people have told me that I was excluded from the program without telling me the reason. [Did you ask the reason why you were excluded?] I thought I was replaced by some officials and I do not want to expose these people. But now I regret for not asking". While Wukro Tagesu has some land, it is not sufficient to grow coffee. Additionally, its productivity is low because she cannot afford fertiliser and during the last two years her crops have failed due to adverse weather conditions. She also "constantly face[s] conflict with my neighbour due to land border. He usually destroys what I sow in the farmland, and then he insults me [...] There is no male or any one that can defend me for that matter". She says she is "worried for the future as the living condition in our area is now getting harder and harder, especially for me" but the only possible course of action is to "encourage my children to finish their education so that they could help me in the future".

Ato Destachew is in his early fifties and has married twice, divorcing his first wife after two years because she hadn't given him a child. He married his second wife when she was 12, which she regards positively as "those girls who were not beautiful and were disobedient married after age of 18 years to a man who is older than them. [...] So, I married [...] at the 
right time". Ato Destachew only studied up to grade two as the school was so far from his home that he injured his foot walking there. His wife did not go to school and describes how "at that time our parents do not allow us to attend school [...] we were not allowed to move out side home alone [...] to protect girls from violence like rape and abduction". Ato Destachew has six children living at home - two have already married - and all but one is enrolled in school (his eldest son has just dropped out of grade 8). However, the children regularly drop out when they cannot afford to buy school materials and clothing: "I told my children that this year I encountered financial problem and I can't help all of them in their schooling. So, some of them agreed to quit this year and resume next year". According to his wife dropping out is also used as a punishment, for example, in the case of her eldest daughter "Her father gets upset easily when she loses her pencil or dropouts her exercise books. He then just decided she [should] dropout without showing sympathy to her". Ato Destachew works as a daily labourer, earning 10 ETB per day, and in PNSP which pays 200 ETB per month. He uses the money from PSNP to buy fertiliser and improved seeds: "I am not a man of trade. So I don't try such activity but when the money is provided timely, I buy quality seed and the seedlings of false banana and plant them timely. I think I can work in such a way and change my life". The household has also taken two dairy cows from the OFSP (the Other Food Support Programme, a compulsory extension and credit programme that is intended to support graduation from PSNP). Their own cow had died while giving birth three years before, which for his wife was a blow "more severe than the death of my parents" since she was feeding the dairy products to their children. They cannot grow coffee as their land is too small, however, they plan to sell sweet potato to pay the new land tax. The children only work on their own land because they are afraid of "people saying that 'all family members including their father are working for cash'" and calling them 'poor'. In the future they hope their living standard will improve because their children will start working and be able to support them. Their main concern at the moment is the cost of the loan to buy the cows: "the authorities told me that I am supposed to pay 1500 Birr per year and to fulfil this I should pay 150 Birr per month [deducted from the 200 Birr his household receives]. But I don't know what total amount I am supposed to pay and in what time interval I am going to finish the payment" (his wife adds that "We fear and feel shame to complain since they gave us the cows to support us").

\subsection{Quantitative analysis}

Tables 5 and 6 below present the distribution of children in households having been identified as chronically poor (i.e. poor or ultra-poor across all 3 rounds), 'new' poor (having become poor or ultra-poor from round 1 to 3 ) and non-poor/ having moved out of poverty on the basis of the mixed methods taxonomy as developed in Roelen and Camfield (2012). An assessment of the shares of each of these poverty groups provides insight into the extent to which particular socio-demographic characteristics and life events are biased to such groups. Table 5 presents results for various socio-demographic characteristics and Table 6 reports on life events.

Table 5. Socio-demographic characteristics

\begin{tabular}{|c|c|c|c|}
\hline & non-poorl nearly poor & chronic poor & 'new' poor \\
\hline & $\%$ & $\%$ & $\%$ \\
\hline \multicolumn{4}{|l|}{ Demographic characteristics } \\
\hline \multicolumn{4}{|l|}{ Sex of child (R3) } \\
\hline Male & 78.5 & 12.5 & 9 \\
\hline Female & 76 & 13.7 & 10.3 \\
\hline Sex of household head (R3) & *** & $* \star *$ & $* * *$ \\
\hline Male & 83 & 10.7 & 6.3 \\
\hline Female & 53.8 & 22.1 & 24 \\
\hline Marital status caregiver (R1) & *** & 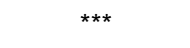 & 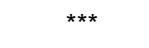 \\
\hline Permanent partner & 82.9 & 10.3 & 6.8 \\
\hline
\end{tabular}




\begin{tabular}{|c|c|c|c|}
\hline Divorced or separated & 46.2 & 25 & 28.8 \\
\hline Single & 55.6 & 22.2 & 22.2 \\
\hline Widowed & 55.9 & 29.4 & 14.7 \\
\hline Gender structure household (R1) & *** & $* \star \star$ & $\star \star \star *$ \\
\hline more males than female & 85 & 7 & 7.9 \\
\hline more females than males & 70.2 & 18.9 & 11 \\
\hline equal numbers & 77.1 & 12.5 & 10.4 \\
\hline Age of household head & 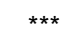 & $* \star \star$ & $\star \star \star *$ \\
\hline$<=30$ & 55.6 & 22.2 & 22.2 \\
\hline $31-35$ & 60.6 & 18.2 & 21.2 \\
\hline $36-40$ & 60.9 & 29.7 & 9.4 \\
\hline $41-45$ & 81.4 & 8.8 & 9.8 \\
\hline $46-50$ & 84.4 & 8.3 & 7.3 \\
\hline $51-55$ & 81.8 & 13.6 & 4.5 \\
\hline $56-60$ & 85.5 & 5.5 & 9.1 \\
\hline $61-70$ & 75.6 & 12.8 & 11.5 \\
\hline$>+71$ & 77.8 & 11.1 & 11.1 \\
\hline \multicolumn{4}{|c|}{ Education level of household head (R1) } \\
\hline Completed primary & 71.6 & 18.9 & 9.5 \\
\hline Did not complete primary & 76.5 & 13.6 & 9.9 \\
\hline Missing & 84.6 & 6.7 & 8.7 \\
\hline Disability household head & * & * & * \\
\hline disabled & 58.3 & 25 & 16.7 \\
\hline not disabled & 78.4 & 12.3 & 9.3 \\
\hline Region of residence & *** & 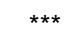 & 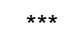 \\
\hline Amhara & 65.2 & 17 & 17.8 \\
\hline Oromia & 88.2 & 8.1 & 3.7 \\
\hline SNNP & 68.8 & 21.7 & 9.4 \\
\hline Tigray & 86.7 & 5.6 & 7.7 \\
\hline
\end{tabular}

Results in Table 5 indicate that particular demographic groups are more prone to experiencing chronic poverty and moves into poverty. Whilst boys and girls in the sample are similarly distributed across the three poverty groups, children living in households that are headed by women are significantly more likely to be chronically poor or have experienced a decline into poverty. Similarly, children living in households with a household head that is divorced, separated or widowed are more likely to be chronically poor or newly poor in comparison to their peers living in households headed by someone with a permanent partner. The gender structure of the households also leads to significant differences; children in households with more men than women are less likely to be chronically poor or to be pushed into poverty. Children living with young household heads or with heads of households that are disabled are more likely to be chronically poor or to have experienced a push into poverty than their peers living with household heads who are not disabled. Children living in Amhara are disproportionately represented in the group of 'new' poor, whilst children living in SNNP are more likely to be chronically poor. Education of the household head does not lead to significant differences. 
Table 6. Life events

\begin{tabular}{|c|c|c|c|}
\hline & non-poorl nearly poor & chronic poor & 'new' poor \\
\hline & $\%$ & $\%$ & $\%$ \\
\hline \multicolumn{4}{|l|}{ Receipt of transfers } \\
\hline \multicolumn{4}{|l|}{ Transfers (R1) } \\
\hline no transfers & 79.2 & 13.5 & 7.3 \\
\hline received transfers & 75.1 & 12.4 & 12.4 \\
\hline \multicolumn{4}{|l|}{ Transfers (R2) } \\
\hline no transfers & 79.4 & 11.8 & 8.7 \\
\hline received transfers & 72.4 & 16 & 11.7 \\
\hline Transfers (R3) & * & * & * \\
\hline no transfers & 80.6 & 10.6 & 8.8 \\
\hline received transfers & 72.2 & 17 & 10.8 \\
\hline Beneficiary of PSNP (R3) & * & * & * \\
\hline no & 80.8 & 11.9 & 7.4 \\
\hline yes & 72.9 & 14.6 & 12.5 \\
\hline Graduated from PSNP (R3) & * & * & * \\
\hline no & 76.5 & 13.6 & 9.8 \\
\hline yes & 95.8 & 0 & 4.2 \\
\hline \multicolumn{4}{|l|}{ Negative events affecting family } \\
\hline \multicolumn{4}{|l|}{ \# events R1 } \\
\hline no event & 78.9 & 11.3 & 9.9 \\
\hline 1 event & 59.4 & 20.3 & 20.3 \\
\hline 2 or more events & 79.9 & 12.2 & 7.9 \\
\hline \multicolumn{4}{|l|}{ \# events R2 } \\
\hline no event & 75.5 & 9.4 & 15.1 \\
\hline 1 event & 71.9 & 18.8 & 9.4 \\
\hline 2 or more events & 78.4 & 12.6 & 9 \\
\hline \multicolumn{4}{|l|}{ \# events R3 } \\
\hline no event & 71.4 & 14.3 & 14.3 \\
\hline 1 event & 63.9 & 19.4 & 16.7 \\
\hline 2 or more events & 78.4 & 12.6 & 9 \\
\hline
\end{tabular}

The quantitative analysis suggests that the receipt of transfers does not play an important role in driving poverty status in either round; the shares of the non-poor, chronic poor and 'new' poor are not statistically different between those receiving or not receiving transfers. Being a PSNP beneficiary does point towards significant differences, which is likely a reflection of adequate targeting. The large majority of households that have graduated from PSNP are non-poor or nearly poor, suggesting that graduation from PSNP can reflect moves out of poverty. In contrast to findings from the literature review and qualitative analysis, the quantitative analysis does not suggest that multiple shocks make households more or less likely to be chronically poor or pushed into poverty. These inconclusive results may be due to quantitative surveys' inability to pick up on subtle events that may have far-reaching consequences and vice versa. 


\section{Discussion}

One of the most important maintainers identified in previous studies of poverty in Ethiopia (reviewed in Camfield and Roelen, 2011) is location. This is confirmed by the quantitative analysis, suggesting that residence in a particular region, notably Amhara and SNNP, leads to significant differences in the share of households being newly poor or chronically poor. As discussed in the literature review, this degree of geographic variability often leads to incorrect pictures of poverty and vulnerability across Ethiopia as a whole. Within the qualitative sample, however, households that were becoming or remaining poor were evenly distributed across the four sites. This seems like a surprising finding from the qualitative analysis given that two of the sites were relatively remote and two grew cash crops (vegetables and coffee) for urban markets. However, respondents in Buna, a coffee-growing area in SNNP, described the instability of the price of coffee while respondents in Zeytuni, a remote village in Tigray, had relatively lucrative off-farm employment dressing and crushing stone for government road building programmes or erecting houses in the expanding local town. This suggests that while location is important, the direction of its influence at the micro-level cannot always be predicted.

Another finding from the literature is that declines into poverty are rarely caused by single events (in fact arguably they are not caused by events at all, but by social processes, see for example, Green and Hulme, (2005) on relational aspects of chronic poverty). This finding is confirmed by the QCA where the poverty drivers it identifies - lack of rainfall, family illness, lack of labour and high food prices - are clearly related. Poor climate lowers everyone's productivity, increasing the demand for and price of food; family illness decreases available labour, as well as increasing expenditure on treatment; and lack of labour - often as a result of illness - means that families need to share-crop out their land, which further reduces the produce that they receive from their plots and means that they need to purchase additional food.

Lack of land is also important factor maintaining households in poverty, particularly in Leki where households were awaiting a re-allocation of land by the government. Within our sample, households headed by women were share-cropping out their land on unfavourable terms and for women in Tach Meret (highland Ethiopia) this may have been because it would not be appropriate for them to plough it. Household heads who are widows may also have had their land reallocated to their deceased husband's family. Other households in our sample experience reduced plot size as the number of adult household members increases and land is shared across generations (Ato Gemechu describes how he has given threequarters of his land to his sons). The effect of reduced plot sizes is a reduction in food security, which is exacerbated by a shrinking of the common land due to an increase in commercial farming (this makes it harder for households with small plots to keep livestock, removing another means of increasing their income).

Drivers such as location, lack of land and experience of multiple shocks are also in evidence in the case study households whose histories have many similarities, despite coming from different sites and spanning a range of household types. For example, they are located in cash-cropping areas, but can't benefit themselves due to lack of land or oxen to plough it. Even where they have a valuable asset such as irrigated land, they can't afford inputs to make best use of it. The household heads and their spouses were not educated themselves and cannot afford to send their children to school with the appropriate materials. This means that even when they are enrolled, they dropout periodically because as Ato Destachew's wife says "my children do not like to learn without getting basic things [needs]". The households are understandably risk adverse, bearing in mind the likelihood of losing investments in seedlings or cattle through drought or disease (for example, the two cows Wukro Hanamariam received from SIDA, the Swedish International Development Agency). While they have benefitted from 
PSNP in the past, many of the households now receive less income due to a reduction in the number of household members covered or deductions for credit, or have been excluded altogether. This makes them more vulnerable to health shocks that have already caused asset sales in all the households.

None of the households describe themselves as well-connected (in the context of decision making around the PSNP quotas) and Wukro Tagesu and Ato Tufa describe feeling marginalised in the Kebele. When asked if he participates in Kebele decision making Ato Tufa says "our membership is just at home. It is useless since we can't see and read. That is why we don't go". Ato Tufa's comment highlights the role of local social, authority and governance structures in maintaining poverty in that social norms and prohibitions, such as cultural restrictions on women ploughing and administrative restrictions on travel to the local town, act as a further constraint on social mobility (our thanks to Frank Ellis for this observation).

It has to be noted that all the household-specific problems described above take place in the broader context of diminishing land holdings, worsening climate, and rising costs of living, which means that households may find it harder to move out of poverty in the future. The only driver not identified in the analysis was being of ethnic minority, although some respondents from Tigray described the problems caused by being in a resettlement area and so remote from their social networks. 'Customs/ traditional practice' was less important than some of the other drivers, except in the case of female-headed households such as Wukro Tagesu's who were less able to defend their rights in community fora and often failed to receive a fair share of their husband's assets after his death.

Finally, whilst the quantitative analysis does not offer conclusive results with respect to the interplay of adverse shocks or the receipt of transfers, it clearly indicates that demographic characteristics matter. Households with relatively more men are more likely to belong to the group of non-poor or upwardly mobile households than households with equal or higher numbers of women, presumably relating to the causal factor of lack of labour that emerged from the QCA. The characteristics of the household head are also of importance. Living in a household that is headed by a woman, someone who does not have a permanent partner, is disabled or is young is likely to increase the risk of falling into poverty and decrease the chances of moving out. Poverty in female-headed households is not a new observation; however, it is worth noting that this is not only to do with lack of land and labour, but also women's relative disempowerment in Ethiopian rural society, illustrated by exclusion from PSNP, disputes over land with predatory neighbours or family members, etc. Education of the household head does not appear to be a significant driver. The ability to gain insight into the demographic characteristics that are associated with significant differences can be seen as a particular advantage of quantitative analysis in mixed methods approaches. The use of data across the sample as a whole allows for assessing the significance of differences across different groups in a way that is not possible when using a subsample for qualitative analysis.

\section{Conclusion}

Our substantive findings largely confirm those of other studies of poverty drivers and maintainers in rural settings. For example, in the qualitative analysis the number and timing of shocks emerged as important, as did social networks and political connections in accessing government support (Davis, 2011; Du Toit and Neves, 2007). The political and economic exclusion experienced by female and older household heads, illustrated by Ato Tufa's comments on Kebele decision-making, may partially account for the higher rates of poverty in this group and highlights the danger of representing poverty "as an entity to be attacked external to the social relations that generate it" with a focus on the characteristics of the poor rather than of the relations in which they are embedded (Green and Hulme, $2005: 868)$. Bearing in mind the need to look at structural forms of disadvantage as well as 
proximal causes of poverty at individual and household levels, we found that while demographic characteristics such as life stage were clearly important, as Baulch (2011) proposes, individual characteristics such as personality (Narayan et al, 2009) were much less evident in the life histories.

Climate or more specifically rainfall emerged as important for every site and type of household suggesting that proposals for rainfall insurance should be pursued alongside incentives to make risky investments in fertilisers, new seeds, and animals (more than half of the sample mentioned animal death as a driver of their poverty). Own and family illness were also important, in part because of the importance of labour in rural areas, and this impacts strongly on children (Camfield and Roelen, 2011, and experiences of Atos Gemechu and Destachew). Debt was less important than in other settings, e.g. Davis (2011), possibly due to lack of credit. However, it still affected nearly a third of households and caused considerable stress, e.g. the unspecified payment to the government for Ato Destachew's cows. The continuing importance of PSNP in rural livelihoods is confirmed by the finding that all the households who had been excluded from PSNP (50\% of the sample) saw it as a cause of further decline rather than a 'graduation'. Despite the findings of, e.g. Bigsten et al (2003) about the importance of connections to markets in avoiding poverty, connections do not appear to matter much when households do not have the resources to take advantage of them (e.g. by irrigating their land to grow cash crops). Finally, the common assertion that it is combinations of factors that drive households into poverty rather than single events is confirmed by the QCA findings as they show high food prices, which were mentioned by slightly over half of the households, acting as the final straw when combined with the more common and related experiences of drought, illness, and labour shortages.

The main findings of the paper are methodological, however, through its use of life histories, analysed using both quantitative and qualitative methods, and longitudinal quantitative data to generate and test hypotheses/findings on poverty drivers and maintainers in rural Ethiopia. The paper uses multiple forms of data and analysis, including hybrid forms such as QCA, and the analysis is lead by the qualitative findings and extensive literature review. The paper not only mixes different types of data, but also iterates between different forms of qualitative and quantitative analysis. This enables it to confirm the generalisability of the findings within a larger sample without losing the connection between cases (individuals, households) and variables (attributes of those individuals and households). Despite its advantages, however, linking up quantitative and qualitative data and methods poses challenges, especially when building on secondary data sources (Irwin, 2010). As research questions have been framed post-data collection, the life histories and quantitative data may not be equipped to provide detailed answers to those research questions. Whilst information on particular issues (such as interplay between events or number of shocks) may be available in the qualitative data, this is not available in the quantitative data. In relation to the qualitative data, we can obtain a broader perspective than many studies by analysing data from two household members rather than one. This enables a movement from 'individual' life stories to studies of 'linked lives' within a household, including the experiences of children within those households. The life histories provide, then, not only a list of poverty drivers and maintainers for testing, but also a very real sense of how these combine in the lives and experiences of individual households. 


\section{References}

Baulch, B, Scott, L. (2006). Report on CPRC workshop on panel surveys and life history methods

www.chronicpoverty.org/uploads/publication_files/2006_Q2_Workshop_Report.pdf

Baulch, B. (ed) (2011). Why poverty persists: poverty dynamics in Asia and Africa (Gloucester: Edward Elgar).

Baulch, B, Vu, D.H. (2011). Poverty dynamics in Vietnam, 2002-2006. In: Baulch, B. (ed) (2011). Why poverty persists: poverty dynamics in Asia and Africa (Gloucester: Edward Elgar).

Bevan, P. (2005). Studying Multi-Dimensional Poverty in Ethiopia: towards a Q-Integrated Approach'. Q-Squared Working Paper series, 15, Toronto

Bevan, P. (2009). Working with Cases in Development Contexts: Some Insights from an Outlier, in: D. Byrne and C. Ragin (eds), Handbook of Case-Centred Methods (London: Sage).

Bevan, P. and Pankhurst, A. (2007) Power Structures, Agency and Community Dynamics in Rural Ethiopia Paper prepared for the Empowerment team in the World Bank.

Bigsten, A., Bereket Kebede, Abebe Shimeles, Mekonnen Taddesse (2003) Growth and poverty reduction in Ethiopia: evidence from household panel surveys, World Development, 31(1): 87-106.

Bird, K., Shinyekwa, I. (2003). Multiple Shocks and Downward Mobility: Learning from Life Histories of Rural Ugandans. Chronic Poverty Research Centre Working Paper No. 36.

Bird, K., Higgins, K. and McKay, A. (2010). 'Conflict, education and the intergenerational transmission of poverty in Northern Uganda'. Journal of International Development, 22 (7), 1183-1196.

Bird, K. (2011). Life histories resource pack. Chronic Poverty Research Centre toolbox, downloaded from http://www.chronicpoverty.org/publications/details/life-historiesresource-pack 04/05/2012.

Bird K., Prowse, M. (2009) Vulnerability, poverty and coping in Zimbabwe. CPRC Working Paper 136, Manchester.

Brannen, J. (2005) NCRM Methods Review Papers, NCRM/005. Mixed Methods Research: A discussion paper. Discussion Paper. Unpublished.

Byrne, D. (2009). Using cluster analysis, qualitative comparative analysis and NVivo in relation to the establishment of causal configurations with pre-existing large- $\mathrm{N}$ datasets: Machining hermeneutics, in: D. Byrne and C. Ragin (eds), Handbook of Case-Centred Methods (London: Sage).

Camfield, L., Roelen, K. (2011) Household trajectories in rural Ethiopia - what can a mixed method approach tell us about the impact of poverty on children? DEV working paper series \#34. 
Carter, M.R., Barrett, C.B. (2006). The Economics of Poverty Traps and Persistent Poverty: An Asset-Based Approach," Journal of Development Studies, 42(2): 178199.

Davis, P. (2011). Passing on poverty: the intergenerational transmission of wellbeing and ill-being in rural Bangladesh. Chronic Poverty Research Centre Working Paper series, 192, University of Manchester, UK.

Davis, P., Baulch, B. (2009). Parallel Realities: Exploring Poverty Dynamics using Mixed Methods in Rural Bangladesh. Paper presented at 'Escaping Poverty Traps: Connecting the Chronically Poor to Economic Growth' conference, Washington DC, February 26-27, 2009.

Dercon, S, Krishnan, P (2000) 'Vulnerability, seasonality and poverty in Ethiopia', Journal of Development Studies, 36(6): 25-53.

Dercon, S. (2006). Economic reform, growth and the poor: Evidence from rural Ethiopia. Journal of Development Economics, 81: $1-24$.

Dercon, S., Shapiro, J.S. (2007). Moving on, staying behind, getting lost: Lessons on poverty mobility from longitudinal data. Global Poverty Research Group, Working Paper series, 75, University of Manchester, UK.

Dercon, S., Porter, C. (2011). A Poor Life? Chronic Poverty and Downward Mobility in Rural Ethiopia, 1994 to 2004. In: Baulch, B. (ed) (2011). Why poverty persists: poverty dynamics in Asia and Africa (Gloucester: Edward Elgar).

Devereux, S., Sharp, K. (2006) Trends in poverty and destitution in Wollo, Ethiopia, Journal of Development Studies, 42(4): 592-610

De Weerdt, J. (2010) Moving out of Poverty in Tanzania: Evidence from Kagera. Journal of Development Studies, 46(2): 331-349.

Du Toit, A. (2004). 'Social Exclusion' Discourse and Chronic Poverty: A South African Case Study. Development and Change, 35(5): 987-1010.

Du Toit, A., Neves, D. (2007). In Search of South Africa's Second Economy: Chronic poverty, vulnerability and adverse incorporation in Mt Frere and Khayelitsha. CPRC working paper \#102.

Elder, G.H. Jr. (1985). "Perspectives on the Life Course." pp23-49 in Life Course Dynamics, edited by Glen H. Elder Jr., Ithaca: Cornell University Press.

Ellis, F., T. Woldehanna. (2005). Ethiopia participatory poverty assessment 2004-05. Addis Ababa: Ministry of Finance and Economic Development.

Emirie, G, W. Negatu, and D. Getachew (2009) 'Impacts of Productive Safety Net Programme on Child Poverty Reduction: Implications for Child Education', Young Lives IDRC Paper, Addis Ababa.

Green, M., Hulme, D. (2005), 'From Correlates and Characteristics to Causes: Thinking About Poverty from a Chronic Poverty Perspective', World Development, 33(6):86779.

Hulme, D., Moore, K., Shepherd, A. (2001). Chronic poverty: Meanings and analytical frameworks, Chronic Poverty Research Centre Working Paper 2, Manchester. 
Irwin, S. (2010) 'Working across qualitative and quantitative data. Childhood, youth and social inequalities', Forum 21. European Journal on Child and Youth Research 6 [12]: 58-63.

Kothari, U, Hulme, D. (2004). Narratives, stories and tales: understanding poverty dynamics through life histories. Global Poverty Research Group Working Paper \#11.

Krishna, A. (2007) Subjective Assessments, Participatory Methods and Poverty Dynamics: The Stages-of-Progress Method, CPRC Working Paper 93, Manchester: Chronic Poverty Research Centre.

Lawson, D. (2006). Quantitative and qualitative approach to understand poverty and inequality dynamics in Uganda. Collection of life history data based on 1992/99 household panel. Unpublished report.

Lloyd-Sherlock, P and C. Locke (2008) 'Vulnerable relations: Life course, wellbeing and social exclusion: Insights from older people's narratives, Buenos Aires', Ageing and Society. 28 (8): 117-1207.

Locke, C., Lloyd-Sherlock, P. (2011). Linked Lives. Subjectivities and Shifting Contexts: Critical Reflections from Development Studies on Qualitative Life Course Methodologies. Development and Change 42 (4):1131-52.

May, J, Woolard, I, Baulch, B. (2011).Poverty traps and structural poverty in KwaZula Natal, South Africa, 1994-2004. In: Baulch, B. (ed) (2011). Why poverty persists: poverty dynamics in Asia and Africa (Gloucester: Edward Elgar).

Miller, R., Mathenge, M., Bird, K., Karin, F., Gitau, R., Kaloi Nteza, E. (2011). Ascending out of poverty: An analysis of family histories in Kenya. CPRC Working Paper 219.

Miller, R. (2007). Using Family Histories to Understand the Intergenerational Transmission of Chronic Poverty. CPRC Working Paper 103.

Narayan, D., Pritchett, L. and Kapoor, S. (2009) Moving Out of Poverty, Volume 2: Success from the Bottom Up (Basingstoke: Palgrave Macmillan).

Narayan, D. (2003). Moving Out of Poverty: Growth and Freedom from the Bottom-Up. A Global Study Proposal. PREM, World Bank.

Ojermark, A. (2007). Presenting Life Histories: A literature review and annotated bibliography. CPRC Working Paper 101.

Olsen, W K. (2009). Non-Nested and Nested Cases in a Socio-Economic Village Study, in: D. Byrne and C. Ragin (eds), Handbook of Case-Centred Methods (London: Sage).

Outes-Leon, I, Dercon, S. (2008). Survey attrition and attrition bias in Young Lives. Young Lives Technical Note 5.

Ragin, C.C. (1987). The Comparative Method: Moving Beyond Qualitative and Quantitative Strategies. Berkeley/Los Angeles/London: University of California Press.

Ritchie, J., Spencer, L. (1994). Qualitative data analysis for applied policy research. In: A. Bryman and R. Burgess (eds.). Analysing qualitative data, London: Routledge, pp.173-94. 
Roelen, K., Camfield, L. (2012). A mixed-method taxonomy of child poverty - the case of Ethiopia. Young Lives working paper series \#76.

Seeley, J. (2008). 'The intergenerational transmission of poverty during the AIDS epidemic in Uganda'. Chronic Poverty Research Centre Working Paper series, 110, University of Manchester, UK.

Shepherd, A. (2011). Tackling chronic poverty: The policy implications of research on chronic poverty and poverty dynamics. Chronic Poverty Reports.

Woldehanna, Tassew, Tekie Alemu and Alemu Mekonnen (2008) Young Lives: Ethiopia Round 2 Survey Report (Oxford: Department for International Development).

World Bank (1999) Ethiopia: Poverty and Policies for the New Millennium (Washington, DC: World Bank).

Yin, R. (2003). Case study research, design and method (Newbury Park: Sage). 